\title{
'Feed them First, Then Ask Virtue of Them': Broadening and Deepening Freedom of Movement
}

\author{
Andrea Sangiovanni
}

\begin{abstract}
Maurizio Ferrera's contribution is characteristically sharp, engaged, and imaginative. In this comment, I will not unpack his various proposals. Rather, I want to discuss the way the issues are framed, and propose an alternative way of grounding them.
\end{abstract}

\section{Citizenship as an instrument for bonding and integrating}

'In the light of rising Euroscepticism, souvranisme and anti-immigration ... sentiments', Ferrera wonders under what conditions EU citizenship might play a more integrative role in European politics. Currently, EU citizenship only secures a thin set of entitlements (to nondiscrimination activated only when an EU citizen is involved in activities or situations that cross an internal EU border), and only secures them for a tiny fraction of the European population (primarily those who actually exercise their rights to freedom of movement, which amounts to less than 5 per cent of the EU population). Ferrera's proposals for reform aim both to broaden and deepen the appeal of EU citizenship, mainly by securing a novel set of entitlements to immobile citizens and by extending the range of social entitlements available to those who move.

Given Ferrera's insistence that EU citizenship should play a more 'integrative role', the criteria by which we should judge whether his proposals would be successful, assuming they were ever adopted, are therefore explicitly functional. We should endorse the proposals if and insofar as they enhance the perceived legitimacy of further European social integration and if and insofar as they increase support for freedom of movement. Ferrera writes, 'I have argued that it is precisely the provision of instrumental resources (money, benefits and services, infrastructures and so on) that could make EU citizenship more salient, visible and tangible for wide social constituencies. A smart enhancement and packaging of such resources ... could be the trampoline for strengthening the social citizenship dimension of the EU...' It is as if Ferrera were to say: 'We (European elites?) agree that further European social integration and freedom of movement are desirable; 
the task that remains is to get EU publics to agree with us. How might we do that? By enhancing the symbolic, material, and instrumental significance of European citizenship in such and such ways. "Feed them first, then ask virtue of them""1

What is odd about such a perspective is that it cannot be offered to EU publics themselves. Imagine a member of the public asks: 'And why should I aim to augment European citizenship in the ways you propose?' Given how Ferrera has framed his question, the answer must be: 'Because it will get you to bond more with fellow Europeans and therefore assent to further EU social integration without undermining freedom of movement'. But that's no answer at all, given she is asking why she should assent to the proposals, bond with other Europeans, and support freedom of movement in the first place.

To be sure, there is nothing wrong with making an argument intended to propose reforms that might feasibly sustain the European project in the face of growing scepticism. And yet there is still something lacking. This contrast can be sharpened if we further imagine that EU publics in fact reject Ferrera's proposals (despite the evidence that Ferrera has marshalled that indicates some support for the general direction). Should one abandon them as therefore misguided? Or might there be something still to be said for them? What might we say, for example, to an engaged, publically minded EU citizen that rejects Ferrera's proposals because they believe either that (a) freedom of movement is a mistake (as many British do, including those who voted for Remain), (b) freedom of movement should remain formally open to all but without further support for either movers or stayers, or (c) freedom of movement should not be limited to EU nationals (but extended to all third-country nationals [TCNs] as well)?

\section{Broadening and deepening freedom of movement}

In the following, I want to sketch a response that provides an alternative basis for Ferrera's proposed reforms while addressing (a) and (b).

With our publically minded EU citizen in view, what is the best argument in favour of EU-wide freedom of movement? One might argue that the free movement of persons is an essential aspect of the Single Market, and, as such, is to be recommended mainly as a device for securing a more efficient allocation of the factors of production. This is an advantage that leads,

As the Grand Inquisitor says in Dostoevsky, F. (1991), The Brothers

Karamazov. R. Pevear and L. Volokhonsky (trans.), New York: Vintage Books, 253. 
through productivity gains, to aggregate gains. But there is also an advantage, in principle, from the perspective of each individual. Freedom of movement and nondiscrimination expands every EU citizen's choice set, providing them with an expanded range of opportunities both to seek gainful employment abroad and to pursue broader cultural, social, political and personal interests. ${ }^{2}$

But, as Ferrera and others have rightly pointed out, freedom of movement also brings costs - costs, furthermore, that do not fall equally on everyone. In particular, there is some (albeit heavily contested) evidence that, while there are net aggregate economic benefits from greater immigration, some communities, some groups, and indeed some member states will inevitably lose out. In the same way as any shift in technology, say, from candlesticks to electric bulbs, will diminish the pay and bargaining power of the candlestick makers (or displace them entirely), the same can be said with immigration: a greater supply of cheaper, unorganised labour will put downward pressure on wages and diminish the bargaining power of those who work in immigrant-heavy sectors. At the same time, public services (education, healthcare, social services, etc.) in communities in which newly arrived immigrants concentrate will bear relatively greater burdens than other communities. Finally, member states that are net senders of immigrants may suffer brain drain, as their skilled labour force moves abroad. ${ }^{3}$ These costs are most often borne not by the well-off but by those who are already disadvantaged. Our member of the public will want some explanation for why she must bear these costs to make way for gains that accrue mostly to others.

The best response will appeal to a broader conception of social justice for the European Union. ${ }^{4}$ Consider that, in integrating, member states and their peoples open their societies, polities, economies, and territories to international and supranational control. By pooling sovereignty, member states and their peoples of course stand to gain, but the constraints of intergovernmental bargaining and supranational control often expose states both to a range of negative externalities and to risks and costs that they can no longer con-

2 This point is well made in Vandenbroucke, F. (2017), 'Basic Income in the European Union: A Conundrum Rather Than a Solution', SSRN Research Paper 2017/02, The Amsterdam Centre for Contemporary European Studies.

3 To calibrate this effect, one must also take into account that many of the CEEC countries were happy to support free movement as it served as a means of relieving excessive labor supply. See, e.g., 'M. Kahanec, Labor Mobility in an Enlarged European Union', in International Handbook on the Economics of Migration, A. Constant and C. Zimmerman (eds.), Cheltenham: Edward Elgar Publishing, 2013, pp. 137-52 and references cited therein.

4 For this point, see also the contribution by D. Thym 'The failure of Union Citizenship beyond the Single Market' in Part II of this book. 
front on their own. To face them, member states depend on the collaboration and cooperation of other member states and supranational actors. To name but one example, think of the constraints of monetary union, and the relative position of Greece and Germany within it. As I argue elsewhere ${ }^{5}$, the best normative model for deciding how these benefits, costs, and risks ought to be distributed is grounded in a conception of reciprocity: member state peoples owe one another a fair return for their mutual submission to EU rules and supervision. The fair return for risks and losses is, in turn, best captured by the idea of a hypothetical insurance market, in which member state peoples know the risks associated with integration but not their place in that distribution. On this view, member state peoples and their citizens are owed a fair division of the gains - which are secured mainly through the convergence promised by the implementation of a Single Market - and indemnification against those risks and losses that are a result of integration, and which they could do little to prevent or avoid. This model can be used to support a much broader Social Union among member state peoples than at present (though stopping well short of providing support for an EU-wide federal welfare state).

We can also use this framework to address our hypothetical members of the public and their concerns with respect to freedom of movement (recall [a] and [b]). ${ }^{6}$ As I have said, freedom of movement brings benefits, but with these benefits also come costs that fall disproportionately on some. Those on whom such costs fall - those whose communities, services, career opportunities and wages are most affected - have a claim, according to the reciprocity-based view of social justice I have just outlined, to be indemnified against these losses in exchange for their support for freedom of movement as a whole. The logic of this reciprocity-based view reinforces and undergirds Ferrera's proposals for an EU fund (modelled on the Globalisation Adjustment Fund) to ease the impact of mobility on affected groups. Although this is not discussed by Ferrera, we could also imagine extending the fund to provide for education and vocational programs in countries suf-

5 See Sangiovanni, A. (2013), 'Solidarity in the European Union', Oxford Journal of Legal Studies 33 (2): 213-241; Sangiovanni, A. (2012), 'Solidarity in the European Union: Problems and Prospects', in J. Dickson \& P. Eleftheriadis (eds.) Philosophical Foundations of European Union Law, 384-412. Oxford: Oxford University Press; Sangiovanni, A. (forthcoming), The Bounds of Solidarity: International Distributive Justice, Reciprocity, and the European Union. Cambridge: Harvard University Press. Here of course I can only briefly sketch the model.

6 I say more about the tension - and how to resolve it — between facilitating freedom of movement and domestic commitments to social solidarity in Sangiovanni, A. (2013), 'Solidarity in the European Union', see above. 
fering from brain drain. This addresses the member of the public who wonders why she should support freedom of movement in the first place, given the costs involved (see [a] above), and, at the same time and in the other direction, addresses those who wonder why they have a duty to support those who bear the costs, given the aggregate benefits.

From within such a reciprocity-based conception of social justice for the EU, what can be said on behalf Ferrera's proposals for 'empowering the stayers'? In this category, Ferrera includes, among other things, a proposal for a universal and transferable voucher system intended to compensate those who do not exercise their rights to freedom of movement. Here we can invoke again our member of the public who, in (b) above, wonders why freedom of movement should guarantee anything more than a formal right to move. An appealing response points to the difference between a merely formal and a more substantive equality of opportunity, not generally (i.e., with respect to all socioeconomic opportunities - as in Rawls's Fair Equality of Opportunity principle - which would require vastly more redistribution across EU member states) but with respect to opportunities to exercise, more specifically, freedom of movement. Recall that one rationale for freedom of movement is an expansion of every EU citizen's opportunity set. The value of that opportunity set to each individual will be very unequal if some can exercise the option to move easily and others, through no fault or choice of their own, cannot - for example, because they have dependents or lack sufficient resources to make use of that freedom. (Here I register a small disagreement with Ferrera, who does not distinguish - from the point of view of their respective entitlements - between those immobile citizens who freely choose to stay and those whose choice is much more constrained. ${ }^{7}$ ) In those cases, providing merely formal freedom of movement unfairly disadvantages those who cannot easily move. As in the previous case, we can say that they have a reciprocity-based entitlement to compensation derived from their support for freedom of movement as a whole.

The same logic, finally, can be used to buttress Ferrera's perhaps most ambitious proposal, namely to set up a social insurance scheme - a kind of mobility fund - protecting workers who decide to exercise their free movement rights. Such a fund would have the effect of mitigating inequalities of opportunity to move that are due to differences, for example, in the exportability of benefits for mobile jobseekers. As Bruzelius et al. have shown, given differences in the exportability of benefits for jobseekers and limitations

7 See also the useful discussion in Part II of this book by K. Oberman. 'What to Say to Those Who Stay? Free Movement is a Human Right of Universal Value'. 
in access to social benefits for jobseekers in host states, it is much easier for someone to move from Britain to Latvia in search of work than the other way around. ${ }^{8}$ An EU-funded mobility fund of the kind advocated by Ferrera would serve, among other things, to dampen these inequalities and so, once again, to address our hypothetical member of the public in (b).

\section{The duties of citizenship}

In his comment, Christian Joppke wonders whether an excessive emphasis on the duties of citizenship betrays an anachronistic and potentially dangerous revival of what we might call Romantic citizenship. Allegiance and loyalty, death and ethnic belonging, exclusion of those who do not share in the myths of national identity, suspicion of immigrants, and so on, are the foundation stones of Romantic citizenship. To be sure, Ferrera invokes none of these in defence of his proposals, but Joppke worries that Ferrera's proposals (whose aim is to strengthen allegiance to EU citizenship) have an unavoidably exclusionary ring to them. They both give too much credence to those who falsely see movers as 'benefit tourists' or (in the language of the CJEU) 'unreasonable burdens', and threaten to impose an artificial divide between EU citizens (who are entitled to the benefits of freedom of movement Ferrera advocates) and TCNs (who are not).

I think that that Ferrera has a ready response. The first step is to emphasize that not all 'citizenship duties' are made equal. Ferrera here can easily agree with Joppke (as I, too, would) that the set of Romantic duties are outmoded and dangerous. But citizenship also includes more prosaic duties, e.g., to pay one's taxes, as well as duties of civility, toleration, and, indeed, justice. These are duties that flow from what Rawls calls citizens' 'sense of justice'. It is these duties that support Ferrera's proposals, not the Romantic ones. This becomes especially clear if we interpret those duties as obligations of reciprocity in the ways I have suggested. From this point of view, we do owe those whose communities, wages, and so on, are most affected indemnification - but this duty is compatible with both requiring evidence of such effects and with acceptance of the fact that movers are, on average, a net benefit - socially, culturally, fiscally, economically, politically - to the polity as a whole.

What about the divide between TCNs and EU citizens (and so [c] above)? Here the response - again within a reciprocity-based perspective - is

8 Bruzelius, C., C. Reinprecht \& M. Seeleib-Kaiser (2017), 'Stratified Social Rights Limiting EU Citizenship', Journal of Common Market Studies 55 (6): 1239-1253. 
straightforward. Because legally resident TCNs participate in their host society's political, civil, social, economic life (in the relevant sense) to the same extent as EU citizens, they bear the same duties and are owed the same benefits and advantages as member state citizens (even if they are economically inactive). ${ }^{9}$ And because of their legal residence in their host country, they also contribute willy-nilly to the European project. Recall that TCNs, too, contribute - in the same way as EU citizens - to the project of integration both in complying with laws enacted or constrained by the European legal order and in contributing (politically, socially, economically, etc.) in ways that ultimately support and sustain European institutions (and EU freedom of movement). To be sure, such an extension of duties and entitlements is not currently on the agenda, but the point is that it should be as a matter of justice. If Ferrera were to qualify his functionalism (which gives perhaps too much credence to the current state of public opinion), I do not see why a conclusion like this would not be available to him as well.

In this comment, I have not sought to challenge Ferrera's proposed reforms. Rather, I have sought to ground them, not in a functional-empirical analysis of what is most likely to inspire support for EU citizenship, but in a broader conception of social justice. The two perspectives are not in direct competition, but they do depart from very different starting points.

Open Access This chapter is licensed under the terms of the Creative Commons Attribution 4.0 International License (http://creativecommons.org/licenses/by/4.0/), which permits use, sharing, adaptation, distribution and reproduction in any medium or format, as long as you give appropriate credit to the original author(s) and the source, provide a link to the Creative Commons license and indicate if changes were made.

The images or other third party material in this chapter are included in the chapter's Creative Commons license, unless indicated otherwise in a credit line to the material. If material is not included in the chapter's Creative Commons license and your intended use is not permitted by statutory regulation or exceeds the permitted use, you will need to obtain permission directly from the copyright holder.

9 I say much more about the grounds for such reciprocity in Sangiovanni, A. (2007), 'Global Justice, Reciprocity, and the State', Philosophy \& Public Affairs 35 (1): 2-39. 